\title{
The Level Of Corporate Dividend Payout To Stockholders: Does Optimal Dividend Policy Exist For Firms Quoted At The Nairobi Stock Exchange?
}

\author{
Bitok Kibet, Moi University, Kenya \\ Tenai Joel, Moi University, Kenya \\ Cheruiyot Thomas, Moi University, Kenya \\ Maru Loice, Moi University, Kenya \\ Kipsat Mary, Moi University, Kenya
}

\begin{abstract}
The objective of this study was to determine the level of corporate dividend payout to stockholders and establish if the optimal dividend policy exists for the firms quoted at the Nairobi Stock Exchange (NSE). An analysis was done for the all the 43 firms trading in the main investment market at the Nairobi Stock Exchange. Secondary data was obtained from the Nairobi Stock Exchange library, Internet \& company libraries. Companies that were quoted at the stock exchange for a period of thirteen years and paid and/or did not pay dividends during that period were sampled. According to the findings of this study, the aggregate dividend payout ratio for the Kenyan market was obtained to be 44.14\% for the period between 1991-2003. The findings of this research suggest that the average corporate dividend payout to stockholders for $40 \%$ of the firms is low and stable and that $28 \%$ of the firms quoted paid out high and stable dividends. It was also observed that most of the firms that paid high and stable dividends are the blue chip firms, which are the main movers of trading at the NSE. The dividend model provides a summary of the factors that influenced and continue to influence the dividend decisions for this market including and not limited to the tax systems, clientele preferences, signaling, sustainability, low liquidity, high growth, ownership control and dividends as residual etc. From the model it is possible to predict the likely dividend decisions of the firms in future.
\end{abstract}

Keywords: dividends, optimal dividend policy, corporate dividend payout ratio

\section{INTRODUCTION}

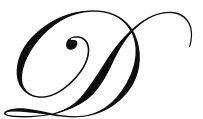

ividend policy is the determination of the proportion of profits paid out to shareholders - usually periodically. The issue to be addressed is whether there exists an optimal dividend policy where shareholders wealth can be enhanced by altering the pattern and size of dividend. Dividends refer to the distribution of earnings. The common ways of distributing part of a firm's value to its owners include payment of cash dividends, repurchasing of stock and payment of stock dividends. Cash dividend is used more often while repurchasing of stocks is not possible in all countries. Stock dividends do not have real values and when paid after cash dividends they are perceived to convey positive information about future cash flows. Dividend policies are influenced by many factors. The legal rules provide that dividends be paid from earnings. Contractual constraints could restrict payment of dividends. Other factors considered include cash needed to repay debt, stability of earnings and growth prospects. Market considerations with respect to access to capital markets are also important. John Lintner (1956) observes that corporate managers are averse to changing the dollar amount of dividends in response to changes in earnings, particularly when earnings decline. Three of the more commonly used dividends policies are constant payout ratio, regular dividend policy, and low-regular and extra dividend policy. 
The dividend policy of the firm is irrelevant in a perfect capital market because the shareholders can effectively undo the firm's dividend strategy. If a shareholder received a greater dividend than desired, he or she can reinvest the excess funds. Conversely, if the shareholder received a smaller dividend than desired, he or she can sell off extra shares of stock. The argument is due to MM and is similar to their homemade leverage concept. Even in a perfect capital market, a firm should not reject positive NPV projects to increase dividend payments. Although the MM argument is useful in introducing the topic of dividends, it ignores many factors in practice. We show that personal taxes and new-issue costs are real-world considerations that favor low dividend payouts. With personal taxes and new issue costs, the firm should not issue stock to pay a dividend. However, our discussion does not imply that all firms should avoid dividends. Rather, those with high cash flow relative to positive NPV opportunities might pay dividends due to legal constraints and/or lack of investment opportunities. The expected return on a security is positively related to its dividend yield in a world with personal taxes. This result suggests that individuals in low or zero tax brackets should consider investing in high-yielding stocks. However, the results do not imply that firms should avoid all dividends.

\section{STATEMENT OF THE PROBLEM}

Dividend theories have been advanced with protagonists taking sides with irrelevance of dividend polices to the value of the firm on one hand and relevance on the other. The dividend irrelevance propositions advanced by Modigliani and Miller (MM), conclude generally that a company's dividend-earnings retention does not affect the owner's wealth and therefore is irrelevant in a perfect financial market because investors can accept the company's decision or costlessly reverse its effect on their portfolio by selling or buying shares in the financial market. The determinant of value is the availability of projects with positive NPVs and the pattern of dividends makes no difference to acceptance of these. The conditions under which this was held to be true include;- There are no taxes, there are no transaction costs, all investors can borrow and lend at the same interest rate, and all investors have free access to all relevant information. Given this assumptions, dividend policy can become relevant (Arnold, 2002). If dividends are irrelevant to a firm's value, the firm therefore does not need to have a dividend policy. On the other extreme position is the residual dividend policy, where the only source of finance for additional investments is earnings. In this world dividends should only be paid when the firm has financed all its positive NPV projects. Once the firm has provided for all the projects which more than cover the minimum required return, investors should be given the residual. In this circumstances dividend policy becomes an important determinant of shareholders' wealth; If cash flow is retained and invested within the firm at less than required return on equity capital shareholders' wealth is destroyed, therefore it is better to raise the dividend payout rate. if on the other hand retained earnings are insufficient to fund all positive NPV projects, shareholder value is lost and it will be beneficial to lower the dividends. Some key questions are yet to be resolved in discussing issues pertaining to corporate dividend payout to stockholders. These questions are whether there exists an optimal dividend policy. If it does exist, is there a model that can be used to evaluate dividend policies in view of optimal dividend policy?

\section{OBJECTIVES OF THE STUDY}

Two main objectives were identified for this study: -

1. To determine the level of the corporate dividend payout to stockholders for the firms that are quoted at the Nairobi Stock Exchange.

2. To establish if the optimal dividend policy exists for the firms quoted at the NSE.

In order to attain the objectives of this study, the following research questions were formulated:

1. What is the average dividend payout ratio for the firms quoted at the Nairobi Stock Exchange?

2. Does the optimal dividend policy exist for the firms quoted at Nairobi Stock Exchange?

3. What model could be used to predict the optimal dividend payout by the firms quoted at the Nairobi Stock Exchange? 


\section{REVIEWED LITERATURE}

The three main decisions of the firm are the investment, financing and the dividend decisions. The dividend decisions are important because they determine the payout received by stockholders and the funds retained by the firm for investment. The critical question in dividend policy is whether there exists an optimal dividend policy and whether it has an influence on the value of the firm given the firm's investment decisions.

Numerous empirical studies fail to provide conclusive evidence in support of the intuitively appealing dividend relevance argument. However, in practice the actions of the intuitively appealing dividend relevance argument holds. Hence, the actions of financial managers and stockholders alike often tend to support the believe that dividend policy does affect the stock value. Investor preferences for receiving dividends have been addressed by Gordon (1962) and Lintner (1963) in the Bird in the Hand theory. Litzenberger and Ramaswamy advanced the tax differential theory where they note that there is a tax advantage of capital gains over dividend hence more shareholders prefer retention to payout. They observe that investors tend to prefer firms with low payouts. Ezra Solomon contends that dividends possess informational value while Jensen observes that dividends reduce managerial control over free cash flow.

In the real world, factors exist which favor a high dividend policy. Graham, Dodd and Cottle argue that firm's should generally have high dividend payouts because; The discounted value of near dividends is higher than the present worth of distant dividends and Between two companies with generally the same earning power and same general position in an industry, the one paying the higher dividend will almost always sell at a higher price. The proponents of the desire for current income and the resolution for uncertainty have upheld these arguments. However, the dividends puzzle remains, and will continue to present an important area for future research. Basically, the problem is that there is an optimal payout policy that the management of a company are attempting to target, imperfectly, in a complete financial environment. Alternatively, an observed dividend effect may simply be superficial and be indicative of profound underlying changes in a company's future prospects.

\section{THE DIVIDEND POLICY DEBATE}

There are two questions, which are at the core of the dividend policy debate. The first question is whether changing the pattern of dividends over a period of years can increase the shareholder wealth? The other question; is a steady, stable dividend growth rate better than one, which varies from year to year depending on the firm's internal need for funds?

The answer to the first question is 'yes'. The accumulated evidence suggests those shareholders for one reason or another value particular pattern of dividends across time. But there is no neat, simple, straightforward formula into which we can plug numbers in order to calculate the best pattern. It depends on numerous factors, many of which are unquantifiable, ranging from the type of clientele shareholder the firm is trying to attract to changes in the taxation system.

Taking the residual theory alone the answer to the second question is that the dividend will vary from year to year because it is what is left over after the firm has retained funds for investment in all available projects with positive NPV. Dividends will be larger in years of high cash flow and few investment opportunities, and will be reduced when the need for reinvestment is high relative to internally generated cash flow. However, in practice, shareholders appear to prefer stable, consistent dividend growth rates. Many of them rely on a predictable stream of dividends to meet (or contribute to) their consumption needs. They would find an erratic dividend flow inconvenient. Investors also use dividend policy changes as an indication of a firm's prospects. A reduced dividend could send an incorrect signal and depress share prices.

There are so many factors influencing dividend policy that it is very difficult to imagine that someone could develop a universally applicable model which would allow firms to identify an optimal payout ratio. The Dividend model shows the range of forces pulling managers towards a high payout rate, and other forces pulling towards a low payout rate. Simultaneously, there are forces encouraging a fluctuating dividend and other factors promoting a stable dividend. 
Dividends require an outflow of cash from firms; therefore companies with plentiful liquid assets, such as cash and marketable securities, are more able to pay a dividend. Other firms, despite being highly profitable, may have very few liquid assets. For example, a rapidly growing firm may have a large proportion of its funds absorbed by fixed assets, inventory and debtors. Thus some firms may have greater difficulty paying cash dividends than others.

Lenders generally prefer to entrust their money to stable firms rather than ones that are erratic, as this reduces risk. Therefore it could be speculated that a consistent dividend flow helps to raise the credit standing of the firm and lowers the interest rates payable. Creditors suffer from information asymmetry as much as shareholders and may therefore look to this dividend decision for an indication of managerial confidence about the firm's prospect.

Figure 1: The Dividend Decision Model

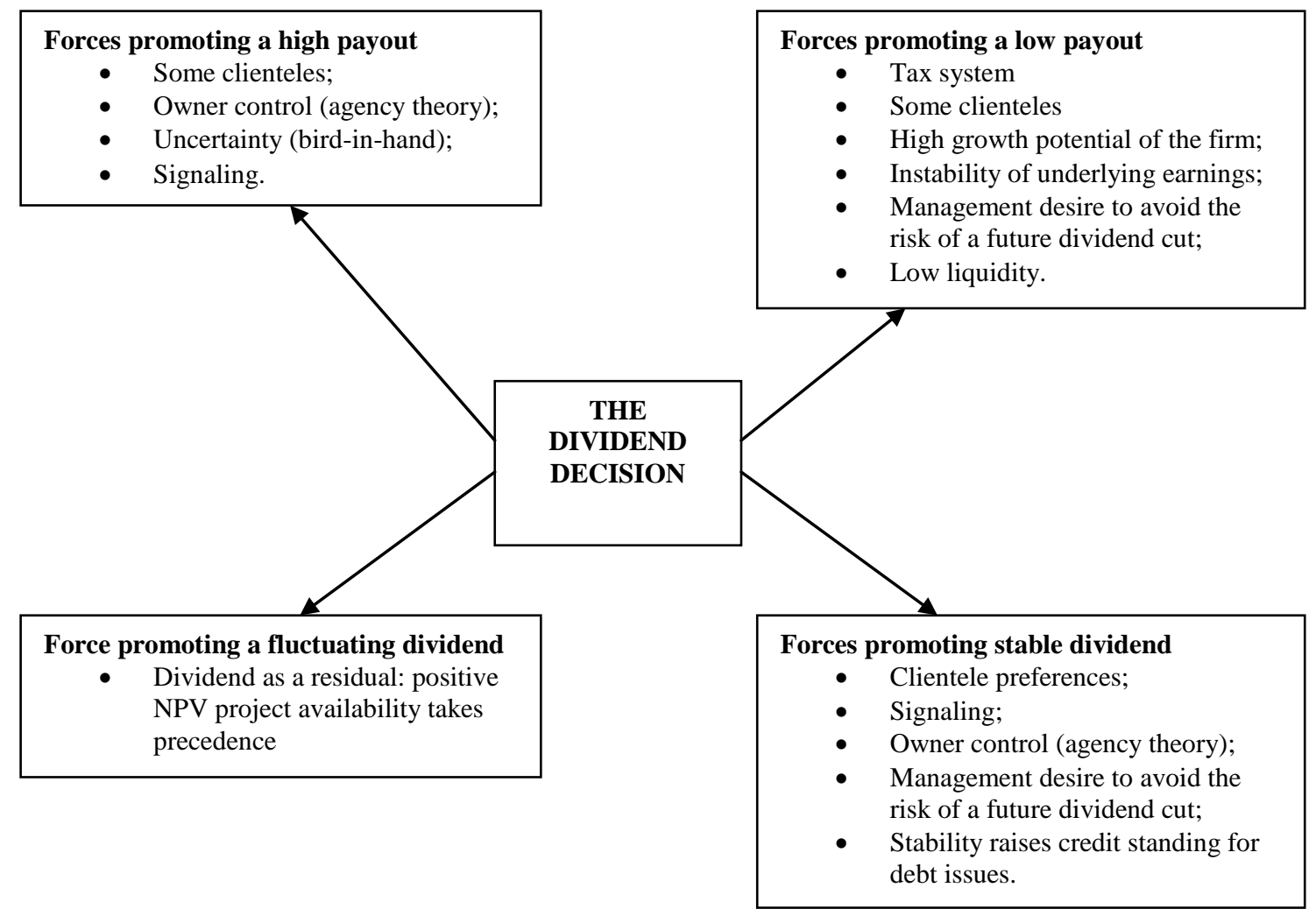

\section{HOW MUCH DIVIDENDS TO PAY?}

According to the Constant payout ratio, a firm will pay a fixed dividend rate e.g. $40 \%$ of earnings. The dividend per share would therefore fluctuate as the earnings per share changes. Dividends are directly dependent on the firm's earnings ability and if no profits are made any dividends are paid. This policy creates uncertainty to ordinary shareholders especially who rely on dividend income and they might demand a higher required rate of return (Gitman, 1998).

Constant Amount Per Share or Fixed Dividend Per Share is where the dividend per share (DPS) is fixed in amount irrespective of the earnings levels. This creates certainty and is therefore preferred by shareholders who have a high reliance on dividend income. It protects the firm from periods of low earnings by fixing, DPS at a low level. This policy treats all shareholders by giving a fixed return. The DPS could be increased to a higher level if earnings appear relatively permanent and sustainable. 
Under the Constant Dividend Per Share Plus Extra/ Surplus policy, a constant DPS is paid every year. However extra dividends are paid in years of supernormal earnings. It gives the firm flexibility to increase dividends when earnings are high and participate in supernormal earnings. The extra dividends are given in such a way that it is not perceived as a commitment by the firm to continue the extra dividend in the future. It is applied by the firms whose earnings are highly volatile e.g. in the agricultural sector (Gitman, 1998).

On the Residual Dividend Policy, dividends are paid out of earnings left over after all investment decisions have been financed. Dividends will only be paid if there are no profitable investment opportunities available. The policy is consistent with shareholders wealth maximization (Pandey, 1991).

\section{MODE/ FORM OF PAYING DIVIDENDS}

Cash and Bonus Issue or stock dividends are the common forms of paying dividends. For a firm to pay cash dividends, it should have adequate liquid funds. However, under conditions of liquidity and financial constraints, a firm can pay stock dividends (Bonus issue). Bonus issue involves issue of additional shares for free (instead of cash) to existing shareholders in their shareholder's proportion. Stock dividends/ Bonus issue involves capitalization of retained earnings and does not increase the wealth of shareholders. This is because retained earnings are converted to shares (Pandey, 1991).

The other form of paying dividends is through a Stocks Split/Reverse Split. This is where a block of shares is broken down into smaller units (shares) so that the number of ordinary shares increases and their respective par value decreases at the stock split factor. Stock split is meant to make the shares of the company more affordable to low-income investors and increase their liquidity in the market (Brealey and Myers \& Marcus, 1995).

Under the Stocks Repurchase, The company can also buy back some of its outstanding shares instead of paying cash dividends. The shares repurchased or bought back are called treasury stock. Share repurchase allows shareholders to receive the cash payment as a capital gain rather than as dividend income. Share repurchase allows shareholders to receive the cash payment as a capital gain rather than as dividend income. It is important to take cognizant of the fact that spin-offs are not practiced in Kenya at the present time. If some outstanding shares were repurchased, fewer shares would remain outstanding. Assuming repurchase does not adversely affect firm's earnings, the earnings per share of stock would increase. This would result in increase in the market price per share (M.P.S.) and hence the capital gains are substituted for dividends (Hirt, 1980).

\section{INDICATORS OF THE DIVIDEND POLICY}

Observable features of the corporate dividend scene that interest both shareholders and management include dividend yield, dividend payout, frequency of payment, and corporate significance of extras and stock dividends. Not only do dividend yield and payout reveal strong tendencies on an over-all basis, but also some significance appears to be attached to industry groupings. The unanimity of opinion as to the most appropriate being the frequency of payment is overwhelming. Dividends extras and stock dividends occupy a minority position, their purpose when used, seems to be to afford management added flexibility and to compensate for departures from the norm (Walter, 1978).

The dividend yield is defined as the ratio of current cash dividends (annual rate) to the market price of the stock. It measures part of anticipated long-run return to the investor. The other component of the anticipated return is the expected rate of growth in dividends. Due allowances must of course be made for the duration and stability of the growth. As measured by standard and Poor's 500 common stocks, average annual dividend yields have ranged between 2.98 per cent and 7.24 per cent over the past 25 years. The 1964 average of monthly yields was $3.01 \%$. On the assumption that the long run dividend growth rate parallels that for the economy (at say $3.5 \%$ to $4 \%$ p.a.), the anticipated return to the investor has varied from $6.5 \%$ to $11 \%$. Only in the period since 1958, have dividend yields declined below the assumed growth factor (Ross, Westerfield, Jaffe, 1993).

The Dividend Payout Ratio (DPOR) is the ratio of dividends per share to the earnings per share. It shows the proportion of earnings that was paid out as dividends and how much was retained. Classification by industry 
appears to have moderate value at least. The interpretations of payout ratios that relate annual cash dividends to annual earnings reported is far from clear. For one thing, the denomination of the ratio (a single years reported earnings) is a random variable and need not bear a close relationship to normal earnings. This consideration has special relevance in the interpretation of a single payout ratio and affects the over-all distribution to the extent that the sample size in any class is insufficient and the annual earnings are correlated (Walter, 1978).

The area in which there is virtual unanimity of corporate opinion is frequency of declaration and payment of cash dividends. As evidenced by frequency of occurrence of dividends declared, over $97 \%$ of dividends were quarterly. The importance of the preference for quarterly payments, aside from convenience to stockholders and lost to the company, lies in the resultant visibility of the impact of dividend payments upon dividend stock price. With dividends yields in the neighborhood of 3 per cent, the quarterly decline in the market value resulting from the cash dividend should not exceed $0.75 \%$, less some adjustment for the differential between capital gains and personal income taxation. The peak profit from good timing is only about $1 \%$. This suggests that the frequency of payment has some consequences.

A number of firms that desire to gear cash dividends more closely to current earnings that is feasible through regular quarterly dividends alone employ extra dividends (and label them as such). The idea is to distinguish between sustainable dividends that reveal managerial expectations and dividends that are simply distributions of current earnings. A spokesman for American Enka stated " there is no particular policy on year-end extra dividends; the directors just see where we are at the end of the year and act accordingly." More often than not, extras are declared annually in the fourth quarter, concurrently with regular dividends. Their timing is consistent with the purpose of adjusting cash dividends to current situation. Whether management's decision to divide the dividend stream between regular and extra dividends has any major bearing upon stock values is far from clear. For this to be the case, it would have to be supposed that two elements of a single dividend stream affect shareholder expectations differently from an un-separated dividend stream (Seitz, 1966).

More often that not, stock dividends supplement, rather than take place of cash dividends. As long as the cash dividend per share remains unchanged, the effect of stock dividends is to raise the cash dividend (when adjusted back to the old shares) in the ratio of stock dividends to shares outstanding. The device of the stock dividends thus adds appreciably to the continuity of changes to annual cash dividends. The stock dividend will capitalize a portion of these undistributed earnings, which the board of directors considers should be retained in the business. At the same time, the stock dividend will provide common stockholders with tangible evidence of this investment by issuing additional shares to them and by placing this investment on a dividend-paying basis. It should be stressed that, apart from the effect upon cash dividends, a policy of stock dividends has inherent value of in it's own right. Since neither the anticipated earnings- risk profile nor the allocation thereof to existing shareholders is affected; the value of each stockholder's holdings is presumably unaffected. Associated with increase in shares, therefore is a proportional decrease in value per share (Ross, Westerfield, Jaffe, 1993).

\section{METHODOLOGY}

This study analyzed a sample of 43 firms that are quoted at the Nairobi stock Exchange. The period of study extends from 1991 to 2003.The dividend announcements and the amounts of dividends paid out by the companies were collected. This study used secondary data obtained from the NSE library and extensive library research. Data was also obtained from published reports of companies. The dividend payout ratio of each company was then computed by dividing the dividends per share by the earnings per share for each firm for each year. This was then expressed as a percentage. Dividend payout ratio was considered adequate measure of the dividend policy because it captured the proportion of dividends paid out to total earnings. Companies whose dividend payout was less $50 \%$ were considered to be low payout, whereas those companies whose dividend payout was greater or equal to $50 \%$ were considered high payout. On the other hand, those firms whose standard deviation of dividend payout was greater than $35 \%$ ere regarded unstable, whereas those whose standard deviation of payout was less than that were regarded stable. 


\section{RESULTS}

From the companies that are quoted at the Nairobi Stock Exchange, and from the four sectors i.e. agricultural (A), commercial and services(C), financial and investments (F), and industrial and allied (I) the following results were obtained:

From the results of table 1, it can be observed that $40 \%$ of the firms quoted at the Nairobi Stock Exchange paid out stable and low dividends. The low and stable DPOR is considered sustainable with less risk of dividend cut in the foreseeable future. It also allows the firms room for growth opportunities. Managers of these firms may also be considering the tax shield on capital gains, some clienteles and low liquidity. These firms are envisaged to be operating at the low dividend payout because the business environment in Kenya is that conducive for very high returns. There are also firms that pay Low dividends because they cannot afford to pay a high dividend due to their perennially low profits and other historical factors; e. g. NBK, Carbacid

Table 2 shows firms paying low and fluctuating dividends. Firms paying low and fluctuating dividends are those whose returns are not stable and have not adapted a consistent dividend payout ratio. These are firms, which apply the residual dividend policy in which positive NPV projects take precedence over the dividend payout. These firms are also affected by low liquidity. According to the findings of this study $12 \%$ of firms quoted at NSE pay low and fluctuating dividends.

According to the results and analysis in table 3, firms pay high and stable dividend because they are liquid and also the want to signal information to the market that their future returns are stable. The agency theory (ownership control) and the pressure from the stockholders could also explain the forces motivating high payout. The firms in this category are the most stable firms and most of them are multinational corporations, which are considered market leaders in the four sectors of the main investment market. These are the blue chips of the entire financial market. Although this set of firms account for $28 \%$ of the total number of quoted firms, they are the main movers of trading at the NSE.

From the results in table 4, the high and unstable DPOR by some firms quoted at the NSE is motivated basically by some clienteles and the uncertainty (bird in hand theory). They believe that one bird in hand is worth two in the bush. They prefer certain dividends to uncertain capital gains. Some firms in this category may want to signal important information to the market using the dividends. The other motivating factor is the agency theory (ownership control). This set of firms account for $19 \%$ of all the quoted firms at the NSE.

\section{DISCUSSIONS}

According to the findings of this study, the aggregate dividend payout ratio for the emerging Kenyan market was obtained to be $44.14 \%$ for the period between 1991-2003.The summary of the dividend payout ratios for all firms and the sectoral averages are contained in Appendix I. The findings of this research suggest that the average corporate dividend payout to stockholders for $40 \%$ of the firms is low and stable and that $28 \%$ of the firms quoted paid out high and stable dividends. It was also observed that most of the firms that paid high and stable dividends are the blue chip firms, which are the main movers of trading at the NSE. From the Dividend model it would seem that the decision for a low payout for these companies are influenced by the tax systems, high growth potential of firms, instability of the earnings, and low liquidity forces. Unfortunately, the optimal payout ratio cannot be determined quantitatively. Rather, one can only indicate qualitatively what factors lead to low or high-dividend payout. The general consensus among financial analysts is that the tax effect is the strongest argument in favor of low dividends and the preference for current income is the strongest argument in favor of high dividends. Unfortunately, no empirical work has determined which of these two factors dominates, perhaps because the clientele effect argues that dividend policy is quite responsive to the needs of stockholders. For example, if 40 percent of the stockholders prefer low dividend and 60 percent prefer high dividends, approximately 40 percent of companies will have a low dividend payout, and 60 percent will have a high payout. This sharply reduces the impact of an individual firm's dividend policy and its market price. 
Table 1: Low and Stable DPOR

\begin{tabular}{|c|c|c|c|c|c|c|c|c|c|c|c|c|c|c|c|c|}
\hline COMPANY & SEC & 2003 & 2002 & 2001 & 2000 & 1999 & 1998 & 1997 & 1996 & 1995 & 1994 & 1993 & 1992 & 1991 & AVG & STDEV \\
\hline Rea Vipingo & $\mathrm{A}$ & 60.98 & 0.00 & 0.00 & 0.00 & 40.40 & 40.40 & 40.30 & 50.80 & 30.40 & & & & & 29.25 & 23.48 \\
\hline G. Williams & $\mathrm{A}$ & 70.89 & -12.72 & 48.20 & 83.89 & 24.12 & 22.71 & 23.60 & 22.80 & 73.70 & 85.20 & 10.70 & 13.80 & 35.60 & 38.65 & 31.04 \\
\hline CMC Hold. & $\mathrm{C}$ & 15.90 & 20.49 & 14.85 & 11.35 & 9.29 & 16.13 & 16.10 & 15.40 & 16.60 & 19.50 & 30.70 & 29.30 & 36.60 & 19.40 & 8.00 \\
\hline Standard News & $\mathrm{C}$ & 0.00 & 0.00 & 1.02 & 0.00 & -47.62 & 25.00 & 25.10 & 50.20 & & & & & & 6.71 & 28.49 \\
\hline Kenya Airw. & $\mathrm{C}$ & 66.67 & 31.91 & 19.75 & 0.00 & 35.09 & 40.76 & 35.10 & 40.70 & & & & & & 33.75 & 18.99 \\
\hline NMG & $\mathrm{C}$ & 33.11 & 32.78 & 28.95 & 19.10 & 18.01 & 17.21 & 17.20 & 15.80 & 13.70 & 13.60 & 31.10 & 44.60 & 38.90 & 24.93 & 10.42 \\
\hline NIC Bank & $\mathrm{F}$ & 71.94 & 52.63 & 47.49 & 49.32 & 37.15 & 28.09 & 33.10 & 28.10 & 30.10 & 35.70 & 33.20 & 27.60 & 36.20 & 39.28 & 12.86 \\
\hline K.C.B. & $\mathrm{F}$ & 0.00 & 0.00 & 0.00 & 0.00 & 73.62 & 34.45 & 35.00 & 31.40 & 21.30 & 19.30 & 21.10 & 37.70 & 53.00 & 25.14 & 22.55 \\
\hline CFC Bank & $\mathrm{F}$ & 46.21 & 56.78 & 41.61 & 35.45 & 28.03 & 25.97 & 26.00 & 26.60 & 15.70 & 16.50 & 20.90 & 26.90 & 35.20 & 30.91 & 11.86 \\
\hline N.B.K. & $\mathrm{F}$ & 0.00 & 0.00 & 0.00 & 0.00 & -3.54 & 64.43 & 64.50 & 59.70 & 81.00 & 8.10 & 35.60 & 28.50 & 33.10 & 28.57 & 30.39 \\
\hline Bamburi & $\mathrm{I}$ & 29.59 & 37.31 & 57.80 & 57.80 & 47.77 & 52.09 & 52.30 & 51.20 & 31.10 & 64.90 & 22.40 & 18.30 & 15.40 & 41.38 & 16.56 \\
\hline Kenya Oil & $\mathrm{I}$ & 23.97 & 20.16 & 34.71 & 25.58 & 1.06 & 21.18 & 21.20 & 30.30 & 34.20 & 19.10 & 35.10 & 31.60 & 79.50 & 29.05 & 17.73 \\
\hline Kenya Power & $\mathrm{I}$ & 0.00 & 0.00 & -39.31 & 12.14 & 28.86 & 27.19 & 27.20 & 12.60 & 3.00 & 5.20 & -8.70 & 35.50 & 0.00 & 7.98 & 19.81 \\
\hline E.A.Portland & $\mathrm{I}$ & 109.5 & 28.49 & 10.15 & 7.91 & 7.91 & 39.29 & 24.00 & 66.30 & 44.60 & 10.70 & 7.40 & 9.80 & 0.00 & 28.15 & 30.93 \\
\hline K. Orchards & $\mathrm{I}$ & 0.00 & 0.00 & 17.99 & 17.99 & 17.99 & 17.99 & & & & & & & & 11.99 & 9.29 \\
\hline Carbacid & I & 46.85 & 43.88 & 23.91 & 34.78 & 23.34 & 28.75 & 25.70 & 31.90 & 28.70 & 26.80 & 22.90 & 23.10 & 42.70 & 31.02 & 8.48 \\
\hline MKT AVG & & 35.97 & 19.48 & 19.20 & 22.21 & 21.34 & 31.35 & 31.09 & 35.59 & 32.62 & 27.05 & 21.87 & 27.23 & 33.85 & 27.60 & 6.21 \\
\hline
\end{tabular}

Table 2: Low and Fluctuating DPOR

\begin{tabular}{|c|c|c|c|c|c|c|c|c|c|c|c|c|c|c|c|c|}
\hline COMPANY & SEC & 2003 & 2002 & 2001 & 2000 & 1999 & 1998 & 1997 & 1996 & 1995 & 1994 & 1993 & 1992 & 1991 & AVG & STDEV \\
\hline Kakuzi & $\mathrm{A}$ & 0.00 & 0.00 & 136.9 & 26.65 & 26.65 & 26.65 & 26.60 & 30.30 & 57.90 & 19.30 & 18.00 & 33.70 & 51.50 & 34.93 & 34.72 \\
\hline Eaagads & $\mathrm{A}$ & 104.2 & 0.00 & -93.98 & 109.7 & 62.66 & 51.15 & 51.20 & 49.30 & 50.40 & 57.30 & 32.80 & -28.10 & -20.50 & 32.77 & 55.86 \\
\hline A. Baumann & $\mathrm{C}$ & 0.00 & 149.3 & 0.00 & 37.88 & -62.19 & -23.81 & 2.20 & 0.20 & 26.30 & 0.80 & -3.20 & 0.50 & 45.00 & 13.30 & 48.80 \\
\hline Diamond Trus & $\mathrm{F}$ & 63.16 & 78.43 & 29.13 & 41.03 & 30.77 & -14.25 & 30.10 & -65.50 & 40.30 & 35.40 & 31.20 & 46.60 & 40.80 & 29.78 & 35.56 \\
\hline Unga Group & I & 0.00 & 0.00 & 0.00 & 0.00 & -10.07 & 48.05 & 112.2 & 80.90 & 23.20 & 40.40 & 67.30 & 72.30 & 65.00 & 38.41 & 39.29 \\
\hline MKT AVG & & 33.47 & 45.54 & 14.41 & 43.04 & 9.56 & 17.56 & 44.46 & 19.04 & 39.62 & 30.64 & 29.22 & 25.00 & 36.36 & 29.84 & 12.00 \\
\hline
\end{tabular}


Table 3: High and Stable DPOR

\begin{tabular}{|c|c|c|c|c|c|c|c|c|c|c|c|c|c|c|c|c|}
\hline COMPANY & SEC & 2003 & 2002 & 2001 & 2000 & 1999 & 1998 & 1997 & 1996 & 1995 & 1994 & 1993 & 1992 & 1991 & AVG & STDEV \\
\hline Brooke Bond & $\mathrm{A}$ & 88.65 & 43.76 & 90.91 & 90.91 & 85.11 & 0.00 & 0.00 & 59.10 & 97.80 & 59.60 & 91.10 & 84.60 & 85.90 & 67.50 & 33.87 \\
\hline Express Ken & $\mathrm{C}$ & 0.00 & 0.00 & 0.00 & 98.27 & 98.27 & 83.02 & 59.70 & 59.30 & 55.40 & 61.20 & 45.90 & 58.00 & 59.70 & 52.21 & 33.78 \\
\hline Barclays & $\mathrm{F}$ & 126.4 & 89.06 & 91.52 & 68.49 & 56.58 & 57.20 & 57.40 & 51.90 & 50.50 & 43.20 & 56.10 & 66.00 & 57.10 & 66.90 & 22.34 \\
\hline Stan Chart & $\mathrm{F}$ & 92.49 & 91.26 & 125.0 & 70.21 & 62.28 & 43.67 & 58.00 & 53.80 & 73.00 & 88.30 & 71.00 & 46.20 & 56.00 & 71.63 & 22.76 \\
\hline H.F.C.K. & $\mathrm{F}$ & 7.00 & 0.00 & 122.5 & 81.97 & 60.48 & 46.15 & 46.40 & 45.50 & 38.10 & 41.60 & 31.90 & 51.70 & 66.00 & 48.30 & 28.90 \\
\hline Jubilee Ins. & $\mathrm{F}$ & 38.29 & 62.06 & 59.12 & 45.10 & 45.10 & 39.06 & 39.10 & 63.70 & 53.90 & 67.20 & 56.20 & 31.80 & 53.40 & 50.31 & 11.30 \\
\hline I.C.D.C & $\mathrm{F}$ & 45.55 & 43.86 & 33.22 & 56.60 & 56.60 & 41.19 & 86.70 & 74.20 & 57.40 & 56.20 & 71.20 & 88.30 & 82.20 & 61.02 & 18.04 \\
\hline Total Kenya & I & 70.54 & 0.00 & 34.52 & 34.52 & 52.36 & 112.1 & 112.2 & 80.90 & 23.20 & 40.40 & 67.30 & 72.30 & 65.00 & 58.87 & 32.78 \\
\hline B. A. T. & $\mathrm{I}$ & 85.05 & 173.8 & 68.59 & 65.95 & 46.99 & 71.26 & 71.00 & 71.30 & 75.80 & 61.60 & 60.60 & 79.30 & 85.80 & 78.24 & 30.56 \\
\hline Firestone & I & 60.24 & 100.0 & 82.64 & 68.18 & 68.18 & 69.25 & 69.20 & 67.30 & 76.20 & 75.80 & 47.40 & 0.00 & 0.00 & 60.34 & 29.35 \\
\hline B.O.C. Ken & I & 80.56 & 92.45 & 92.69 & 44.87 & 44.87 & 34.15 & 48.00 & 54.30 & 70.20 & 75.10 & 58.70 & 53.70 & 38.80 & 60.65 & 19.72 \\
\hline Dunlop Ken & I & 125.0 & 125.0 & 52.63 & 66.67 & 45.98 & 46.99 & 45.90 & 47.00 & 45.30 & 38.00 & 28.70 & 27.20 & 29.10 & 55.65 & 32.59 \\
\hline MKT AVG & & 68.17 & 68.44 & 70.16 & 65.98 & 60.23 & 53.67 & 57.80 & 60.69 & 59.73 & 59.02 & 57.18 & 54.93 & 56.58 & 60.97 & 5.45 \\
\hline
\end{tabular}

Table 4: High and Unstable DPOR

\begin{tabular}{|c|c|c|c|c|c|c|c|c|c|c|c|c|c|c|c|c|}
\hline COMPANY & SEC & 2003 & 2002 & 2001 & 2000 & 1999 & 1998 & 1997 & 1996 & 1995 & 1994 & 1993 & 1992 & 1991 & AVG & STDEV \\
\hline Sasini & $\mathrm{A}$ & -61.73 & 34.36 & 10.18 & 156.3 & 93.75 & 76.34 & 76.40 & 99.90 & 99.50 & 79.20 & 30.80 & 67.70 & 80.90 & 64.89 & \begin{tabular}{|l|}
52.80 \\
\end{tabular} \\
\hline Kapchorua & $\mathrm{A}$ & 73.53 & -12.25 & 197.4 & 197.4 & 39.35 & 39.35 & 39.30 & 31.10 & 72.80 & -43.00 & 7.60 & 6.10 & 16.40 & 51.16 & 72.21 \\
\hline Uchumi & $\mathrm{C}$ & 33.56 & 106.7 & 93.81 & 166.7 & 153.8 & 77.16 & 89.40 & 77.00 & 94.90 & 74.00 & 84.20 & & & 95.57 & 37.07 \\
\hline Marshalls & $\mathrm{C}$ & & & 0.00 & 0.00 & 177.0 & 52.98 & 39.30 & 53.00 & 48.10 & 39.30 & 3.70 & 8.50 & 39.30 & 41.92 & 49.64 \\
\hline TPS Serena & $\mathrm{C}$ & 40.15 & 51.16 & 46.51 & 48.78 & 58.14 & 93.46 & 85.40 & 199.1 & & & & & & 77.84 & 52.58 \\
\hline City Trust & $\mathrm{F}$ & 156.3 & 89.69 & 89.29 & 100.0 & 37.74 & 25.73 & 24.70 & 25.70 & 7.20 & 42.70 & 33.70 & 22.30 & 19.50 & 51.88 & 43.47 \\
\hline E.A Cables & $\mathrm{I}$ & -172.41 & 125.0 & 73.33 & 416.7 & 63.69 & 63.69 & 63.40 & 68.60 & 68.70 & 61.20 & 48.30 & 53.30 & 51.60 & 75.77 & 123.4 \\
\hline E.A.B.L. & I & 87.85 & 60.48 & 36.84 & 52.22 & 26.43 & 45.15 & 302.3 & 45.10 & 78.40 & 143.6 & 48.80 & 48.60 & 58.50 & 79.56 & 73.18 \\
\hline MKT AVG & & 22.46 & 65.02 & 68.42 & 61.49 & 81.24 & 59.23 & 90.03 & 74.94 & 67.09 & 56.71 & 36.73 & 34.42 & 44.37 & 64.84 & 30.34 \\
\hline
\end{tabular}


From the study it is noted that many firms appear to have a long-run target dividend policy. Firms that have few (many) positive NPV relative to available cash flow will have high (low) payouts. In addition, firms try to reduce the fluctuations in the level of dividends. There appears to be some value in dividend stability and smoothing. The stock market reacts positively to increases in dividends (or an initial dividend payment) and negatively to decreases in dividends. This suggests that there is information content in dividend payments.

Most large firms forecast their financial position of a few years ahead. Their forecasts will include projections for fixed capital expenditure and additional investment in working capital as well as sales, profits, etc. This information, combined with a specified target debt to equity ratio, allows an estimation of medium- to longterm cash flows.

These companies can then determine a dividend level that will leave sufficient retained earnings to meet the financing needs of their investment projects without having to resort to selling shares. (Not only does issuing shares involve costs of issue but, investors sometimes view share issues as a negative omen.) Thus a maintainable regular dividend on a growth path is generally established. This has the virtue of providing some certainty to a particular clientele group and provides a stable background, to avoid sending misleading signals. At the same time the residual theory conclusions have been recognized, and (over, say, a five-year period) dividends are intended to be roughly the same as surplus cash flow after financing all investment in projects with a positive NPV. Agency costs are alleviated to the extent that managers do not, over the long run, store up (and misapply) cash flows greater than those necessary to finance high-return projects.

\section{CONCLUSIONS}

The objective of this study was to determine the level of corporate dividend payout to stockholders and establish if the optimal dividend policy exists for the firms quoted at the Nairobi Stock Exchange (NSE). According to the findings of this study, the aggregate dividend payout ratio for the emerging Kenyan market was obtained to be $44.14 \%$ for the period between 1991 - 2003. The findings of this research suggest that the average corporate dividend payout to stockholders for $40 \%$ of the firms is low and stable and that $28 \%$ of the firms quoted paid out high and stable dividends. It was also observed that most of the firms that paid high and stable dividends are the blue chip firms, which are the main movers of trading at the NSE. The Dividend Model used in this study summarizes the forces that determine the dividend policy. This model can be used to evaluate and predict the future dividend policies of firms in view of the optimal dividend policy. The dividend decisions for a low payout for these companies are influenced by the tax systems, high growth potential of firms, instability of the earnings, and low liquidity forces. Further, the stable dividend payout observed was largely due to clientele preferences, signaling and stability arising from credit standing.

However, firms in different circumstances are likely to exhibit different payout ratios. Clientele with plentiful investment opportunities will in general, opt for relatively low dividend rates as compared with those that are exhibited by companies with few such opportunities. Each type of firm is likely to attract a clientele favoring its dividend policy. For example investors in fast-growth, high-investment firms are prepared to accept low dividends in return for the prospect of higher capital gains. If a change in dividend policy becomes necessary then firms are advised to make a gradual adjustment, as a sudden break with a trend can send an erroneous signal about the firms.

The future is uncertain and so companies may consider their financial projections under various scenarios. They may focus particularly on the negative possibilities. Dividends may be set at a level low enough that, if poorer trading conditions do occur, the firm is forced to cut the dividend. Thus a margin for error is introduced by lowering the payout rate. Companies that are especially vulnerable to macroeconomic vicissitudes, such as those in cyclical industries, are likely to be tempted to set a relatively low maintainable regular dividend so as to avoid the dreaded consequences of a reduced dividend in a particularly bad year. In years of plenty directors can pay out surplus cash in the form of special dividends or share repurchases. This policy of low regular payouts in good years might not be maintained at the extraordinary level. 


\section{RECOMMENDATIONS}

For an optimal dividend policy to be achieved and maintained I suggested that;

1. Forecast the 'surplus' cash flow resulting from the subtraction of the cash needed for investment projects from that generated by the firm's operations over the medium to long term.

2. Pay a maintainable regular dividend based on this forecast. This may be biased on the conservative side to allow for uncertainty about future cash flows

3. If cash flows are greater than projected for a particular year, keep the maintainable regular dividend fairly constant, but pay a special dividend or initiate a share repurchase programme. If the change in cash flow is permanent, gradually shift the maintainable regular dividend while providing as much information to investors as possible about the reasons for the change in policy.

\section{AUTHOR INFORMATION}

Julius Kibet Bitok, B. Ed.(Maths), M.B.A.(Finance) is a lecturer in the School of Business and Economics, Department of Accounting and Finance, Moi University. He teaches courses in finance and quantitative techniques in business. He has taught for nine years. He is also a doctoral student in Business Management (Finance Option)in Moi University and is in the dissertation phase of the program. Email Address: hezkibet@yahoo.com

Joel Kipngetich Tenai, B. Com., M. Com. is a lecturer in the School of Business and Economics, Department of Accounting and Finance, Moi University. He is also the Head of the Department of Accounting and Finance and teaches courses in accounting, finance, company law, and quantitative techniques in business. He has taught for nine years. He is also a doctoral student in Business Management (Finance Option) in Moi University and is in the dissertation phase of the program. Email Address: ianetjk@yahoo.com

Thomas Kimeli Cheruiyot, BBA., M. Com. is a lecturer in the School of Business and Economics, Department of Marketing and Management Science, Moi University. He teaches management science and quantitative techniques in business. He has taught for eleven years. He is also a doctoral student in Business Management( Strategic Management Option) in Moi University and is in the dissertation phase of the program. Email Address: cherutho@gmail.com

Loice Chepngetich Maru, BBM., M. Phil(ENT) is a lecturer in the School of Business and Economics, Department of Marketing and Management Science, Moi University. She teaches courses in Small and Micro enterprise Development. She has taught for five years. She is also a doctoral student in Business Management( Strategic Management Option) in Moi University and is in the dissertation phase of the program. Email Address: lcmaru@yahoo.com

Kipsat Mary, Bsc., M. Phil, PhD(Agric Econ) is a Senior lecturer in the School of Business and Economics, Department of Economics and Agricultural Resource Management, Moi University. She is also the Dean of the School of Business and Economics. She has taught for Seven years. Email Address: mjkipsat@yahoo.com

\section{REFERENCES}

1. Arnold Glen (2002), Corporate Financial Mangement, $2^{\text {nd }}$ Ed, Prentice Hall-Fin, Pitman Pub., London, GB

2. Bierman H. (1986), Financial Management for Decision Making, Collier Macmillan, New York, U.S.A.

3. Brealey, Myers, Marcus, (1985) Fundamentals of Corporate Finance, McGraw-Hill, New York ,U.S.A.

4. Brigham and House (2004), Fundamentals of Financial Management, 10th Ed, Thompson, Ohio, U.S.A.

5. Brigham \& Gapesnski L. (1994), Financial Management; Theory \& Practice, Dryden, U. S.A.

6. Brigham F. E. (1986), Fundamentals of Financial Management, $5^{\text {th }}$ Edition, Dryden, Hinsdale, U.S.A.

7. Brittain J. A. (1966), Corporate Dividend Policy, Brookings Inst., Washington D.C., U.S.A.

8. Gitman J.(1198), Principles of Managerial Finance, Brief Ed, Addison-Wesley, Mexico, U.S.A.

9. Helfert E. (1966), Valuation, Concepts \& Practice, Wadsworth, Belmont, California, U.S.A.

10. Hirt G. (1981), Fundamentals of Investment Management, Richard, Irwin, Illinois U.S.A. 
11. Kallberg J..(1993), Corporate Liquidity; Management \&Measurement, Irwin, Homewood, U.S.A.

12. Kolb \& Demong (1988), Principles of Financial Management, 2nd Ed, Irwin, Illinois, U.S.A.

13. Levy and Sarnat (1990), Capital Investment and Financial Decisions, $5^{\text {th }}$ Ed. Irwin, Illinois, US

14. Lintner J., 'Distribution of Income of corporations among Dividends Retained and Taxes', American Economic Review, May 1956

15. Lintner John, 'Dividends, Earnings, Leverage, Stock Prices, and the Supply of Capital to Corporations,' Review of Economics and Statistics, August 1962,243-269

16. Myron Gordon, 'Optimal Investment and Financing Policy,' Journal of Finance, May 1963, 264-74

17. Pandey I.M.(1991), Financial Management, Vikas Publishing House, New Delhi, India.

18. Puxity (1991), Financial Management; Methods \& Meaning, Chapman, New York, U.S.A.

19. Ross, Westerfield, Jaffe, (1993), Corporate Finance, $2^{\text {nd }}$ Ed. Irwin, Homewood, U.S.A.

20. Seitz E (1990), Capital Budgeting \& Long-term Financing Decisions, Dryden Press, Chicago, U.S.A.

21. Van Horne J. (1983), Financial Management \&Policy, 6th Ed, Prentice-Hall, Englewood, New Jersey.

22. Walter J.E. (1967), Dividend Policy \& Enterprise Valuation, Wadsworth, Belmont, California, U.S.A.

23. Weston \& Brigham (1981), Managerial Finance, 7th Ed, Dryden, Hinsdale, Illinois, USA 


\section{APPENDIX I}

Table 5: The Level Of Dividend Payout Ratio (\%) For The Market

\begin{tabular}{|c|c|c|c|c|c|c|c|c|c|c|c|c|c|c|c|c|}
\hline COMPANY & SEC & 2003 & 2002 & 2001 & 2000 & 1999 & 1998 & 1997 & 1996 & 1995 & 1994 & 1993 & 1992 & 1991 & AVG & STDV \\
\hline Brooke Bond & $\mathrm{A}$ & 88.65 & 43.76 & 90.91 & 90.91 & 85.11 & 0.00 & 0.00 & 59.10 & 97.80 & 59.60 & 91.10 & 84.60 & 85.90 & 67.50 & 33.87 \\
\hline Kakuzi & $\mathrm{A}$ & 0.00 & 0.00 & 136.99 & 26.65 & 26.65 & 26.65 & 26.60 & 30.30 & 57.90 & 19.30 & 18.00 & 33.70 & 51.50 & 34.94 & 34.75 \\
\hline Rea Vipingo & $\mathrm{A}$ & 60.98 & 0.00 & 0.00 & 0.00 & 40.40 & 40.40 & 40.30 & 50.80 & 30.40 & & & & & 29.25 & 23.48 \\
\hline Sasini & $\mathrm{A}$ & -61.73 & 34.36 & 10.18 & 156.25 & 93.75 & 76.34 & 76.40 & 99.90 & 99.50 & 79.20 & 30.80 & 67.70 & 80.90 & 64.89 & 52.80 \\
\hline G. Williamson & A & 70.89 & -12.72 & 48.20 & 83.89 & 24.12 & 22.71 & 23.60 & 22.80 & 73.70 & 85.20 & 10.70 & 13.80 & 35.60 & 38.65 & 31.04 \\
\hline Kapchorua T. & $\mathrm{A}$ & 73.53 & -12.25 & 197.37 & 197.37 & 39.35 & 39.35 & 39.30 & 31.10 & 72.80 & -43.00 & 7.60 & 6.10 & 16.40 & 51.16 & 72.21 \\
\hline Eaagads & $\mathrm{A}$ & 104.17 & 0.00 & -93.98 & 109.65 & 62.66 & 51.15 & 51.20 & 49.30 & 50.40 & 57.30 & 32.80 & -28.10 & -20.50 & 32.77 & 55.86 \\
\hline Uchumi & $\mathrm{C}$ & 33.56 & 106.67 & 93.81 & 166.67 & 153.85 & 77.16 & 89.40 & 77.00 & 94.90 & 74.00 & 84.20 & & & 95.57 & 37.07 \\
\hline CMC Holdings & $\mathrm{C}$ & 15.90 & 20.49 & 14.85 & 11.35 & 9.29 & 16.13 & 16.10 & 15.40 & 16.60 & 19.50 & 30.70 & 29.30 & 36.60 & 19.40 & 8.00 \\
\hline Standard News & $\mathrm{C}$ & 0.00 & 0.00 & 1.02 & 0.00 & -47.62 & 25.00 & 25.10 & 50.20 & & & & & & 6.71 & 28.49 \\
\hline \begin{tabular}{|l|} 
A. Baumann \\
\end{tabular} & $\mathrm{C}$ & 0.00 & 149.25 & 0.00 & 37.88 & -62.19 & -23.81 & 2.20 & 0.20 & 26.30 & 0.80 & -3.20 & 0.50 & 45.00 & 13.30 & 48.80 \\
\hline Marshalls & $\mathrm{C}$ & & & 0.00 & 0.00 & 176.99 & 52.98 & 39.30 & 53.00 & 48.10 & 39.30 & 3.70 & 8.50 & 39.30 & 41.92 & 49.64 \\
\hline Kenya Airways & $\mathrm{C}$ & 66.67 & 31.91 & 19.75 & 0.00 & 35.09 & 40.76 & 35.10 & 40.70 & & & & & & 33.75 & 18.99 \\
\hline NMG & $\mathrm{C}$ & 33.11 & 32.78 & 28.95 & 19.10 & 18.01 & 17.21 & 17.20 & 15.80 & 13.70 & 13.60 & 31.10 & 44.60 & 38.90 & 24.93 & 10.42 \\
\hline TPS Serena & $\mathrm{C}$ & 40.15 & 51.16 & 46.51 & 48.78 & 58.14 & 93.46 & 85.40 & 199.10 & & & & & & 77.84 & 52.58 \\
\hline Express Kenya & $\mathrm{C}$ & 0.00 & 0.00 & 0.00 & 98.27 & 98.27 & 83.02 & 59.70 & 59.30 & 55.40 & 61.20 & 45.90 & 58.00 & 59.70 & 52.21 & 33.78 \\
\hline Barclays & $\mathrm{F}$ & 124.61 & 89.06 & 91.52 & 68.49 & 56.58 & 57.20 & 57.40 & 51.90 & 50.50 & 43.20 & 56.10 & 66.00 & 57.10 & 66.90 & 22.34 \\
\hline NIC Bank & $\mathrm{F}$ & 71.94 & 52.63 & 47.49 & 49.32 & 37.15 & 28.09 & 33.10 & 28.10 & 30.10 & 35.70 & 33.20 & 27.60 & 36.20 & 39.28 & 12.86 \\
\hline Stan Chart & $\mathrm{F}$ & 92.49 & 91.26 & 125.00 & 70.21 & 62.28 & 43.67 & 58.00 & 53.80 & 73.00 & 88.30 & 71.00 & 46.20 & 56.00 & 71.63 & 22.76 \\
\hline \begin{tabular}{|l|} 
K.C.B. \\
\end{tabular} & $\mathrm{F}$ & 0.00 & 0.00 & 0.00 & 0.00 & 73.62 & 34.45 & 35.00 & 31.40 & 21.30 & 19.30 & 21.10 & 37.70 & 53.00 & 25.14 & 22.55 \\
\hline \begin{tabular}{|l|} 
H.F.C.K. \\
\end{tabular} & $\mathrm{F}$ & 122.45 & 0.00 & 111.11 & 81.97 & 60.48 & 46.15 & 46.40 & 45.50 & 38.10 & 41.60 & 31.90 & 51.70 & 66.00 & 57.18 & 32.65 \\
\hline \begin{tabular}{|l|} 
CFC Bank \\
\end{tabular} & $F$ & 46.21 & 56.78 & 41.61 & 35.45 & 28.03 & 25.97 & 26.00 & 26.60 & 15.70 & 16.50 & 20.90 & 26.90 & 35.20 & 30.91 & 11.86 \\
\hline Diamond Trust. & $\mathrm{F}$ & 63.16 & 78.43 & 29.13 & 41.03 & 30.77 & -14.25 & 30.10 & -65.50 & 40.30 & 35.40 & 31.20 & 46.60 & 40.80 & 29.78 & 35.56 \\
\hline Jubilee Ins. & $\mathrm{F}$ & 38.29 & 62.06 & 59.12 & 45.10 & 45.10 & 39.06 & 39.10 & 63.70 & 53.90 & 67.20 & 56.20 & 31.80 & 53.40 & 50.31 & 11.30 \\
\hline Pan African Ins & $\mathrm{F}$ & 0.00 & 0.00 & -119.86 & 30.22 & 30.22 & 25.22 & 35.30 & 43.90 & 71.50 & 30.60 & 51.80 & 29.00 & 40.90 & 20.68 & 46.27 \\
\hline I.C.D.C & $\mathrm{F}$ & 45.55 & 43.86 & 33.22 & 56.60 & 56.60 & 41.19 & 86.70 & 74.20 & 57.40 & 56.20 & 71.20 & 88.30 & 82.20 & 61.02 & 18.04 \\
\hline N.B.K. & $\mathrm{F}$ & 0.00 & 0.00 & 0.00 & 0.00 & -3.54 & 64.43 & 64.50 & 59.70 & 81.00 & 8.10 & 35.60 & 28.50 & 33.10 & 28.57 & 30.39 \\
\hline \begin{tabular}{|l|} 
City Trust \\
\end{tabular} & $\mathrm{F}$ & 156.25 & 89.69 & 89.29 & 100.00 & 37.74 & 25.73 & 24.70 & 25.70 & 7.20 & 42.70 & 33.70 & 22.30 & 19.50 & 51.88 & 43.47 \\
\hline E.A Cables & I & -172.41 & 125.00 & 73.33 & 416.67 & 63.69 & 63.69 & 63.40 & 68.60 & 68.70 & 61.20 & 48.30 & 53.30 & 51.60 & 75.77 & 123.44 \\
\hline Unga Group & I & 0.00 & 0.00 & 0.00 & 0.00 & -10.07 & 48.05 & 112.20 & 80.90 & 23.20 & 40.40 & 67.30 & 72.30 & 65.00 & 38.41 & 39.29 \\
\hline Total Kenya & $\mathrm{I}$ & 70.54 & 0.00 & 34.52 & 34.52 & 52.36 & 112.07 & 112.20 & 80.90 & 23.20 & 40.40 & 67.30 & 72.30 & 65.00 & 58.87 & 32.78 \\
\hline B. A. T. & I & 85.05 & 173.84 & 68.59 & 65.95 & 46.99 & 71.26 & 71.00 & 71.30 & 75.80 & 61.60 & 60.60 & 79.30 & 85.80 & 78.24 & 30.56 \\
\hline E.A.B.L. & $\mathrm{I}$ & 87.85 & 60.48 & 36.84 & 52.22 & 26.43 & 45.15 & 302.30 & 45.10 & 78.40 & 143.60 & 48.80 & 48.60 & 58.50 & 79.56 & 73.18 \\
\hline \begin{tabular}{|l|} 
Bamburi \\
\end{tabular} & $\mathrm{I}$ & 29.59 & 37.31 & 57.80 & 57.80 & 47.77 & 52.09 & 52.30 & 51.20 & 31.10 & 64.90 & 22.40 & 18.30 & 15.40 & 41.38 & 16.56 \\
\hline Firestone E.A. & $\mathrm{I}$ & 60.24 & 100.00 & 82.64 & 68.18 & 68.18 & 69.25 & 69.20 & 67.30 & 76.20 & 75.80 & 47.40 & 0.00 & 0.00 & 60.34 & 29.35 \\
\hline Kenya Oil & I & 23.97 & 20.16 & 34.71 & 25.58 & 1.06 & 21.18 & 21.20 & 30.30 & 34.20 & 19.10 & 35.10 & 31.60 & 79.50 & 29.05 & 17.73 \\
\hline Athi-River Min & I & 80.65 & 0.00 & 0.00 & 0.00 & 0.00 & 52.63 & 64.50 & 55.40 & & & & & & 31.65 & 34.83 \\
\hline B.O.C. Kenya & I & 80.56 & 92.45 & 92.69 & 44.87 & 44.87 & 34.15 & 48.00 & 54.30 & 70.20 & 75.10 & 58.70 & 53.70 & 38.80 & 60.65 & 19.72 \\
\hline Dunlop Kenya & I & 125.00 & 125.00 & 52.63 & 66.67 & 45.98 & 46.99 & 45.90 & 47.00 & 45.30 & 38.00 & 28.70 & 27.20 & 29.10 & 55.65 & 32.59 \\
\hline Kenya Power & I & 0.00 & 0.00 & -39.31 & 12.14 & 28.86 & 27.19 & 27.20 & 12.60 & 3.00 & 5.20 & -8.70 & 35.50 & 0.00 & 7.98 & 19.81 \\
\hline E.A.Portland & I & 109.49 & 28.49 & 10.15 & 7.91 & 7.91 & 39.29 & 24.00 & 66.30 & 44.60 & 10.70 & 7.40 & 9.80 & 0.00 & 28.16 & 30.95 \\
\hline K. Orchards & $\mathrm{I}$ & 0.00 & 0.00 & 17.99 & 17.99 & 17.99 & 17.99 & & & & & & & & 11.99 & 9.29 \\
\hline Carbacid & $\mathrm{I}$ & 46.85 & 43.88 & 23.91 & 34.78 & 23.34 & 28.75 & 25.70 & 31.90 & 28.70 & 26.80 & 22.90 & 23.10 & 42.70 & 31.02 & 8.48 \\
\hline MRKT AVG & & 44.25 & 39.35 & 39.29 & 61.49 & 43.99 & 40.62 & 49.19 & 49.22 & 50.70 & 42.26 & 36.42 & 35.02 & 43.55 & 44.14 & 33.95 \\
\hline
\end{tabular}

Source; Adapted from the Nairobi Stock Exchange 
Table 6: Sectoral Averages For The Level Of The Dividend Payout Ratio (\%)

\begin{tabular}{|c|c|c|c|c|c|c|c|c|c|c|c|c|c|c|c|c|}
\hline SECTOR & & 2003 & 2002 & 2001 & 2000 & 1999 & 1998 & 1997 & 1996 & 1995 & 1994 & 1993 & 1992 & 1991 & AVG & STDV \\
\hline AGRICULTURAL & A & 48.07 & 7.59 & 55.67 & 94.96 & 53.15 & 36.66 & 36.77 & 49.04 & 68.93 & 42.93 & 31.83 & 29.63 & 41.63 & 45.59 & 43.43 \\
\hline COMMERCIAL & $\mathrm{C}$ & 23.67 & 49.03 & 22.77 & 42.45 & 48.87 & 42.43 & 41.06 & 56.74 & 42.50 & 34.73 & 32.07 & 28.18 & 43.90 & 40.63 & 31.97 \\
\hline FINANCIAL & $\mathrm{F}$ & 63.41 & 46.98 & 42.30 & 48.20 & 42.92 & 34.74 & 44.69 & 36.58 & 45.00 & 40.40 & 42.83 & 41.88 & 47.78 & 44.44 & 25.84 \\
\hline INDUSTRIAL & I & 41.83 & 53.77 & 36.43 & 60.35 & 31.02 & 48.65 & 74.22 & 54.51 & 46.35 & 50.98 & 38.94 & 40.38 & 40.88 & 45.91 & 34.57 \\
\hline MRKT AVG & & 44.25 & 39.35 & 39.29 & 61.49 & 43.99 & 40.62 & 49.19 & 49.22 & 50.70 & 42.26 & 36.42 & 35.02 & 43.55 & 44.14 & 33.95 \\
\hline
\end{tabular}

Source: Adapted from the Nairobi Stock Exchange 